\title{
From Rwanda to Wisconsin: the global relevance of diarrhoeal diseases
}

From refugee camps in Rwanda and Zaire to water faucets in Wisconsin, newly recognised and ancient agents of diarrhoeal disease continue to plague our ever-shrinking globe. In addition to the staggering statistics of morbidity, mortality and economic impact, recent outbreaks in developing and developed regions illustrate the continued relevance of diarrhoeal illness to a sophisticated society confronted with shrinking budgets.

The far-reaching global impact of diarrhoeal diseases can be quantified to some extent by estimates of mortality, morbidity and economic loss. For instance, it is estimated that 3.3-6 million children die annually from diarrhoeal illnesses (>9000-12600 deaths/day), the vast majority in Asia, Africa and Latin America [1-3]. Among the highest rates of diarrhoea morbidity and mortality in the world are those in the north-east of Brazil, where attack rates exceed 6-12 illnesses/ child each year in rural and urban areas, respectively [4, 5], and where childhood mortality approaches $25 \%$ in the first 5 years of life [6]. In this region, over half of all infant and childhood deaths are due to diarrhoea, and the years of potential life lost to diarrhoea may exceed those of all other causes combined [7]. The 1993 World Bank report introduced a new measure of the overall burden of different diseases-the disability-adjusted life year (DALY) index; this combines healthy life years lost because of premature mortality with those lost as a result of disability. Of the communicable diseases listed, diarrhoea ranked second only to respiratory infections, was nearly twice that due to sexually-transmitted diseases including AIDS and nearly 3 times that due to malaria, accounting for $7.3 \%$ of the total DALYs lost worldwide in 1990. Significantly, children $<5$ years old accounted for $>80 \%$ of the DALYs lost from diarrhoea [8]. The overall economic impact of this morbidity and mortality is incalculable, but it is certain that diarrhoeal diseases play a large role in the vicious cycle linking poor health to lack of productivity and marginal economies (not to mention population overgrowth [9]) in many developing countries.

Whereas the economic impact of the diarrhoeal diseases in developing countries defies quantification, in the USA, where such illness is less prevalent, an estimated 25-100 million diarrhoeal illnesses result in 23 billion dollars/year lost in direct medical costs and productivity [10]. Furthermore, diarrhoeal illnesses in

Correspondence should be sent to: R. L. Guerrant, Box 485 Health Sciences Center, University of Virginia School of Medicine, Charlottesville, VA 22908, USA. hospitals, day-care centres, and nursing homes constitute a major health threat and a leading cause of morbidity that is often overlooked [11]. Diarrhoea is also a major predisposing factor to other costly nosocomial infections such as urinary tract infections [12].

Beyond these costs, less quantifiable, but equally significant, repercussions of diarrhoeal illnesses are illustrated in several recent epidemics in the developing and the developed world. The explosive epidemic potential of diarrhoeal illnesses in crowded conditions with poor sanitation was tragically demonstrated recently in concurrent outbreaks of cholera and multidrug-resistant Shigella dysenteriae infection in Goma, Zaire which, in $<25$ days, claimed the lives of more than 41500 Rwandan refugees [13]. The senseless loss of life in these outbreaks reflects the opportunist nature of otherwise easily preventable diarrhoeal pathogens wrought by social upheaval. Clearly, an effective public health strategy requires sharp focus on the root causes of inadequate basic sanitary facilities and water supplies.

In the developed world, the safety of the food supply has been called into question by the more than 20000 infections and 250 deaths associated with Escherichia coli $\mathrm{O} 157: \mathrm{H} 7$ infection in the USA each year [14]. As in most outbreaks, the largest in North America (>700 cases with four deaths) was traced to undercooked ground beef, in this case from a fast-food restaurant chain [15]. Given the far-reaching health and economic consequences of a contaminated food supply, it has been proposed that a microbiological quality grade of food products should be included on package labelling [16]. Recent outbreaks of enterohaemorrhagic E. coli, like those of Salmonella spp. $[17,18]$ have taught us new risks of highly industrialised food production and how extensively we share diverse global food sources. The powerful epidemiological lessons learned from these outbreaks ought to provide the stimulus for government and industry to develop creatively practical and profitable incentives to improve the microbiological safety of our increasingly industrialised food supply.

Similarly, the 1993 outbreak of cryptosporidiosis in Milwaukee, Wisconsin, the largest recognised outbreak of water-borne illness in the history of the USA, highlights the vulnerability of water supplies to this chlorine-resistant pathogen for which no proven therapy exists. Over the span of 2 months, an estimated 403000 cases of diarrhoea occurred despite water quality measures, such as turbidity, being well within the US Environmental Protection Agency standards [19]. Thus, Cryptosporidium parvum, which 
accounts for $6 \%$ of cases of diarrhoea and is readily spread in developing countries [20], has profound epidemic potential even in developed countries where present water safety standards fail to protect us from potentially dangerous (and in immunocompromised patients, incurable) infections. As existing methods of filtration and chlorination are inadequate, a new policy for the treatment of water for drinking is badly needed in both developing and developed areas.

For all the untold suffering, death and devastation wrought on our planet by diarrhoeal illnesses, and amplified by political apathy, some good - in the form of advances in the understanding and practical treatment of diarrhoeal illnesses - has emerged over the past three decades. These advances led to what was considered in 1978 as 'potentially the most important medical advance this century' [21,22], oral rehydration therapy. This ingenious 'low' technology application of a 'high' technology physiological observation continues to save the lives of over 1 million children annually $[23,24]$. Oral rehydration therapy works on the simple princíple that intestinal absorption of sodium is coupled to that of glucose and that addition of glucose to sodiurn-containing solutions continues to drive sodium absorption, even in the face of on-going intestinal secretion. Still further improvements in simple oral therapy, such as supplementation with zinc [25], vitamin A [26], and possibly glutamine [27-29], hold promise for controlling diarrhoea and improving nutritional status both in developing areas and in sophisticated intensive care units.

An increasingly interdependent global economy, expanding international travel, and the recognition of certain diarrhoeal pathogens as 'emerging infections', many of which first plague the developing world before spreading to industrialised wealthier nations, demand an improved approach to diagnosis, prevention, and treatment of diarrhoeal diseases. These diseases teach us above all that we share not only the enteric pathogens with the disadvantaged but also our very destiny and identity in the human family.

N. M. THIELMAN and R. L. GuerRANT Divisions of Geographic and International Medicine and Infectious Diseases, University of Virginia USA School of Medicine, Charlottesville, VA, USA

\section{References}

1. Snyder JD, Merson MH. The magnitude of the global problem of acute diarrhoeal disease: a review of active surveillance data. Bull WHO 1982; 60: 605-613.

2. Warren KS. Tropical medicine or tropical health: The Health Clark Lectures, 1988. Rev Infect Dis 1990; 12: 142-156.

3. Bern C, Martines J, de Zoysa I, Glass RI. The magnitude of the global problem of diarrhoeal disease: a ten-year update. Bull WHO 1992; 70: 705-714.

4. Guerrant RL, Kirchhoff LV, Shields DS et al. Prospective study of diarrheal illnesses in northeastern Brazil: patterns of disease, nutritional impact, etiologies, and risk factors. $J$ Infect Dis 1983; 148: 986-997.

5. Schorling JB, Wanke CA, Schorling SK, McAuliffe JF, de
Souza MA, Guerrant RL. A prospective study of persistent diarrhea among children in an urban Brazilian slum. Patterns of occurrence and etiologic agents. Am J Epidemiol 1990; 132: $144-156$

6. Guerrant RL, Schorling JB, McAuliffe JF, de Souza MA. Diarrhea as a cause and an effect of malnutrition: diarrhea prevents catch-up growth and malnutrition increases diarrhea frequency and duration. Am $J$ Trop Med Hyg 1992; 47: 28-35.

7. Guerrant RL, McAuliffe JF. Special problems in developing countries: In: Gorbach SL (ed) Infectious diarrhea. Boston, Blackwell Scientific. 1986: 287-307.

8. World Bank. World Development Report 1993. New York, Oxford University Press. 1993.

9. Guerrant RL. Twelve messages from enteric infections for science and society. Am J Trop Med Hyg 1994; 51: 26-35.

10. Garthright WE, Archer DL, Kvenberg JE. Estimates of incidence and costs of intestinal infectious diseases in the United States. Public Health Reports 1988; 103: 107-115.

11. Guerrant RL, Hughes JM, Lima NL, Crane J. Diarrhea in developed and developing countries: magnitude, special settings, and etiologies. Rev Infect Dis 1990; 12 Suppl 1: S41-S50.

12. Lima NL, Guerrant RL, Kaiser DL, Germanson T, Farr BM. A retrospective cohort study of nosocomial diarrhea as a risk factor for nosocomial infection. $J$ Infect Dis 1990; 161: 948-952.

13. Levine OS, Swerdlow D, Roberts L et al. Epidemic cholera and dysentery among Rwandan refugees in Goma, Zaire, 1994 35th Interscience Conference on Antimicrobial Agents and Chemotherapy. San Francisco, CA: 1995: K73, p 300.

14. Boyce TG, Swerdlow DL, Griffin PM. Escherichia coli O157:H7 and the hemolytic-uremic syndrome. $N$ Engl $J$ Med 1995; 333: 364-368.

15. Bell BP, Goldoft M, Griffin PM et al. A multistate outbreak of Escherichia coli O157:H7-associated bloody diarrhea and hemolytic uremic syndrome from hamburgers. The Washington experience. JAMA 1994; 272: 1349-1353.

16. Guerrant RL, Theno DM. New challenges to providing safe foods: what about grades for microbiological quality? $N$ Engl $J$ Med 1995; 333: 1711-1712..

17. Hedberg CW, Korlath JA, D'Aoust J-Y et al. A multistate outbreak of Salmonella javiana and Salmonella oranienburg infections due to consumption of contaminated cheese. JAMA 1992; 268: 3203-3207.

18. Anonymous. Multistate outbreak of Salmonella poona infections - United States and Canada, 1991. MMWR 1991; 40: $549-552$.

19. MacKenzie WR, Hoxie NJ, Proctor ME et al. A massive outbreak in Milwaukee of cryptosporidium infection transmitted through the public water supply. N Engl J Med 1994; 331: $161-167$.

20. Adal KA, Sterling CR, Guerrant RL. Cryptosporidium and related species. In: Blaser MJ, Smith PD, Ravidin JI, Greenberg HB, Guerrant RL (eds) Infections of the gastrointestinal tract. New York, Raven Press. 1995: 1107-1128.

21. Leading article. Water with sugar and salt. Lancet 1978; 2 300-301.

22. Newman RD, Zu S-X, Wuhib T, Lima AAM, Guerrant RL Sears CL. Household epidemiology of Cryptosporidium parvum infection in an urban community in northeast Brazil. Ann Intern Med 1994; 120: 500-505.

23. Hirschhorn N, Greenough WB. Progress in oral rehydration therapy. Sci Am 1991; 264(5): 16-22.

24. Guerrant RL, Bobak DA. Bacterial and protozoal gastroenteritis. $N$ Engl J Med 1991; 325: 327-340.

25. Sazawal S, Black RE, Bhan MK, Bhandari N, Sinha A, Jalla S. Zinc supplementation in young children with acute diarrhea in India. $N$ Engl $J$ Med 1995; 333: 839-844.

26. Glasziou PP, Mackerras DEM. Vitamin A supplementation in infectious diseases: a meta-analysis. $B M J$ 1993; 306: 366-370.

27. Rhoads JM, Keku EO, Quinn J, Woosely J, Leece JG. Lglutamine stimulates jejunal sodium and chloride absorption in pig rotavirus enteritis. Gastroenterology 1991; 100: 683-91.

28. Ribeiro HJ, Ribeiro T, Mattos A et al. Treatment of acute diarrhea with oral rehydration solutions containing glutamine. J Am Coll Nutr 1994; 13: 251-255.

29. Lima A, Soares AM, Freire JE et al. Cotransport of sodium with glutamine, alanine and glucose in the isolated mucosa of rabbit ileum. Braz J Med Biol Res 1992; 25: 637-640. 